had known him since the 1880 s, when he was a prominent socialist and unionist, and he was the model for Boanerges in The Apple Cart.

\title{
Shaw Reviews Mrs Pat
}

\author{
LADY RHONDDA
}

From Lady Rhondda, 'GBS and Mrs Pat', Time and Tide, 22 November 1952. Mrs Campbell's intention to publish some of Shaw's letters in her autobiography strained their friendship severely. Shaw casually gave his permission, but when he realised what he had let himself in for, he tried desperately to get all of them excluded (he was especially apprehensive of the effect on his wife). He edited a proof of the chapter but even so uncut versions appeared in a New York paper. Subsequently he withstood all Mrs Campbell's efforts to get permission to publish the entire correspondence. It finally appeared after his death in 1952, when it occasioned Lady Rhondda's article.

GBS once told me quite a lot about his relations with Mrs Campbell. He had come to my flat one day at tea-time, not very long after his wife died. He sat there talking for a couple of hours with his mind travelling back over the past. Among the people he spoke of was Mrs Pat. I had known both him and his wife fairly well for many years and what he told me was exactly what I should have expected. He was certainly a polygamist on paper, but only, I would have judged, on paper.

He spoke that afternoon of Mrs Campbell's My Life and Some Letters, which had been published in 1922. It was a bit awkward, he said. He had given permission for the publication in it of some of his letters, as she was very badly off and the letters would help to sell the book. But when he agreed he had understood that a number of other letters of the same type (she wasn't, he said, the kind of woman to whom any man could write any other sort) from other extremely notable people would be published. Permission to print these had, however, been withdrawn without his knowledge and when the book came out it looked as if he had been about the only man in Mrs Pat's life. Nothing could have been further from the truth.

He had replied to the book in The Apple Cart. In the scene between Magnus and Orinthia he had given an accurate description of his relationship with Mrs Campbell. Some of the passages were, in fact, an almost verbatim record of what had passed between them, as Mrs Pat well knew. 